\title{
Chromosomenpräparation aus einzelnen Blastomeren
}

\author{
O. ROTTMANN
}

Aus dem Lehrstuhl für Tierzucht der Technischen Universität München, Freising-Weihenstephan (R.F.A.)

Die Chromosomenpräparation von Blastomeren, die aus einem Säugerembryo (Kaninchen) entnommen wurden, soll zwei Ziele verfolgen: Zum einen kann damit das Geschlecht des Embryo eindeutig definiert werden, was im Rahmen des Embryonentransfer von Bedeutung ist. Zum andern sollen die Verhältnisse des frühen Embryo untersucht werden. Dabei können vor allem numerische und strukturelle Aberrationen, sowie auch die Banderungseigenschaften der Chromosomen erkannt werden.

Die Präparationsmethode umfasst die Entnahme der Blastomeren aus dem lebenden Embryo unter der Bedingung, dass seine Vitalitat nicht beeinträchtigt wird, und ferner die anschliessende Kurzkultur der wenigen entnommenen Zellen bis zur Metaphase der nachsten Zellteilung. Zur hypotonen Behandlung werden die Zellen auf einen Objektträger gebracht und mit EssigsäureAlkoholgemisch fixiert. Es folgen entweder eine einfache Farbung mit Giemsas -- Lösung oder die G-Bandfärbung.

\section{Cytogenetic examination of 2,4 and 8 cell sheep eggs}

\author{
Susan E. LONG
}

Department of Animal Husbandry, University of Bristol, Langford House, Langford, Bristol BSI8 $7 D U, U . K$.

Examinations pre-implantation blastocysts from pigs (MCFEELY, 1967; Moon, RASHAD, MI, I975) and cattle (MCFEEI,Y and RAJAKOSKI, I968) have revealed number with an abnormal karyotype. In the pig, the commonest abnormality from 88 blastocysts was polyploidy. In cattle, one of eleven blastocysts was a diploid/tetraploid mosaic. However, examination of late pre-implantation blastocysts in sheep has failed to detect any abnormalities (LONG, in press). This led to the speculation that abnormal zygotes, if they were being formed, were degenerating before the 10-1 8 day post coitum period when the examination was taking place. At present, work is being carried out to examine eggs which are still within the zona, from a normal flock of sheep. Two egg collections are made from each animal, one at laparotomy and one at slaughter on day 2 post coitum, the day of service being day $O$. The eggs are cultured for $24 \mathrm{hrs}$. in a medium containing colcemid in an atmosphere of $5 \mathrm{p}$. cent $\mathrm{CO}_{2}$ in air. They are then subjected to a hypotonic solution of sodium citrate and fixed on a slide with one drop of $1: 1$ methanolacetic acid fixative. The hypotonic and fixation treatments are critical in order to obtain well spread metaphase chromosomes and will be discussed in detail. Using this method some eggs have been identified with an abnormal karyotype and this will be discussed in relation to causes of embryonic loss.

\section{Versuche zur Zellhybridisierung}

\author{
M. FORSTER \\ Lehrstuhl für Tierzucht der Techn., \\ Universität München in $805^{\circ}$ Freising, Weihenstephan (R.F.A.)
}

Zellhybridisierungen gewinnen zunehmend an Bedeutung. Die Tatsache, dass beide Genome in der Hybridzelle Genaktivitäten besitzen ist von ausserordentlichem Vorteil. Dieses Material ist sehr geeignet für Fragestellungen wie z.B. Genkartierung, Genregulation, Chromatinkondensation und Transfer von genetischer Informatior. Es wird von Erfahrungen mit verschiedenen Fusionsmethoden berichtet. Herauszustellen ist die Problematik mit Sendai Virus. Auf die Eignung verschiedener Zellinien von landwirtschaftlichen Nutztieren zur Hybridisierung mit Maus - und Hamsterzellen wird eingegangen. 